DOI 10.36622/VSTU.2021.51.3.004

UDC 536.24

\author{
L. A. Kushchev', V. A. Uvarov², N. Yu. Savvin ${ }^{3}$, S. V. Chuikin ${ }^{4}$
}

\title{
INTENSIFIED PLATE HEAT EXCHANGE DEVICE IN HEAT SUPPLY SYSTEMS OF THE HOUSING AND COMMUNAL SERVICES OF THE RUSSIAN FEDERATION
}

\author{
Belgorod State Technological University Named after V. G. Shukhov, \\ Civil Engineering Institute 1, 2,3 \\ Russia, Belgorod \\ Voronezh State Technical University ${ }^{4}$ \\ Russia, Voronezh
}

${ }^{1}$ D. Sc. in Engineering, Prof. of the Dept. of Heat and Gas Supply and Ventilation, e-mail: leonidkuskev@gmail.com
${ }^{2}$ D. Sc. in Engineering, Prof. of the Dept. of Heat and Gas Supply and Ventilation, e-mail: n-savvin@mail.com
${ }^{3}$ PhD student of the Dept. of Heat and Gas Supply and Ventilation, e-mail: n-savvin@mail.ru
${ }^{4}$ PhD in Engineering, Assoc.Prof. of the Dept. of Heat and Gas Supply and Oil and Gas,e-mail: ser.chu@mail.ru

Statement of the problem. The problem of intensification of heat exchange processes in a plate heat exchanger on the basis of the HH№ 02 heat exchanger of the Ridan company is discussed. It is essential to carry out an analysis of the existing methods of intensification of heat exchange processes in plate devices according to the results of the analysis to choose the most promising method of intensification of heat exchange process and based on it to develop a patent-protected design of a heat exchange plate. Laboratory tests of the intensified plate heat exchanger with increased turbulence of the coolant are performed. The results of thermal tests on a specialized laboratory installation of the resulting and the serial heat exchanger are presented.

Results. The results of the comparison of experimental studies of the intensified plate heat exchanger with the increased turbulence of the heat carrier and the serial plate heat exchanger of identical heat power are shown. The graphs of dependence of the heat transfer coefficient, which is the major characteristic of the operation of heat exchange equipment, on the average temperature pressure are designed.

Conclusions. As a result of the laboratory tests in the specialized laboratory of BSTU named after V. G. Shukhov and research at the Voronezh State Technical University established a rise in the heat transfer coefficient due to the increased turbulence of the coolant flow, which causes a decrease in metal consumption and reduces the cost of heat exchange equipment.

Keywords: plate heat exchanger, corrugated surface, experimental studies, heat transfer coefficient, intensification of heat exchange process, turbulence.

Introduction. The territory of the Russian Federation is made up by five climatic zones with the heating period lasting from 72 to 365 days according to a zone [10].

Thus in order to create comfortable working and living conditions, heat supply systems are used in housing and communal services. In Russia, the most common one is the centralized

(C) Kushchev L. A., Uvarov V. A., Savvin N. Yu., Chuikin S. V., 2021 
heat supply as with this type of heat supply guarantees low fuel consumption and operating costs. The advantage is the low degree of air pollution which improves the sanitary condition of settlements [5].

However, in the second half of the $20^{\text {th }}$ century and in the early $21^{\text {st }}$ century, decentralized, autonomous and individual heat supply systems are becoming more common. This is partly due to the extensive cottage construction both in the Russian Federation and in the developed countries of the world [13].

In a decentralized heat supply system, the heat source and the heat sink are practically combined, i.e., the heating network is either very small or absent. Such a heat supply can be individual with separate heating devices used in each room [11]. Decentralized heating differs from centralized heating by local distribution of the produced heat. Small boiler houses, hot water boilers, stove and electric heating, including modern heat pump setups [15] are used as a heat source.

Heat exchange equipment is currently used in heat supply systems, the use of plate devices is particularly advantangeous. They became a real breakthrough in the energy sector of housing and communal services. This is due to the high technical and economic performance of the plate heat exchange equipment. Thus the problem of modernizing and improving the technical characteristics of such equipment is extremely relevant.

The objective of the study is to develop a plate design for intensifying heat exchange processes in plate devices to increase the heat transfer coefficient $\mathrm{K}, \mathrm{W} /\left(\mathrm{m}^{2} \mathrm{~K}\right)$.

\section{Intensification of heat exchange processes in heat exchange equipment. In compliance} with the requirements for heat exchangers, in production for solving problems of heat supply and the choice of equipment, several types of apparatus structures and thus schemes for the movement of heat carriers are selected. Heat carriers with the necessary thermal and hydraulic calculations for the designed heat exchangers are chosen depending on the operating conditions. To conclude, an economic calculation is made taking into consideration the capital investment, profitability, maintenance costs, etc. [14].

In heat supply systems, the most common shell-and-tube and plate heat exchangers as shown in Fig. 1.

In line with the Soviet and Russian experience, shell-and-tube heat exchangers in heat supply systems for housing and communal services are reliable and cost-effective. However, the major disadvantage of this type of equipment is the low heat transfer coefficient $\mathrm{K}, \mathrm{W} /\left(\mathrm{m}^{2} \mathrm{~K}\right)$, in comparison with plate heat exchangers [3, 4]. 
a)

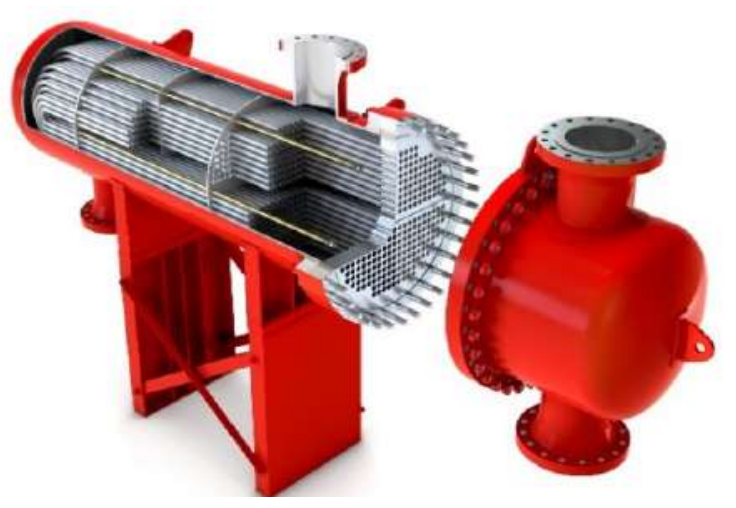

b)

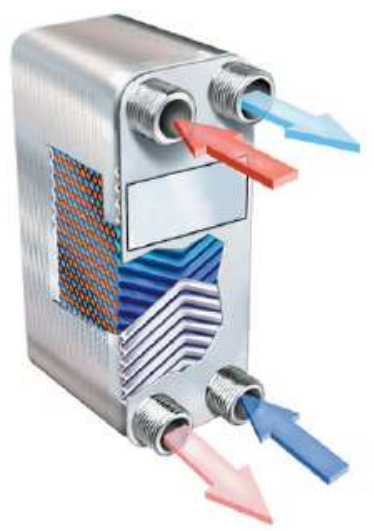

Fig. 1. Heat exchange equipment:

a) shell-and-tube heat exchanger; b) plate heat exchanger

The use of plate heat exchangers in heat supply systems for housing and communal services leads to an increase in the heat transfer coefficient $\mathrm{K}, \mathrm{W} /\left(\mathrm{m}^{2} \mathrm{~K}\right)$ as well as that in the efficiency of a substation due to a decrease in the amount of subcooling and a drop in labor costs during repair and maintenance. Such advantages are accounted for by small overall dimensions with a high value of the heat transfer coefficient $\mathrm{K}, \mathrm{W} /\left(\mathrm{m}^{2} \mathrm{~K}\right)$. Thus an increase in the energy efficiency of technological equipment of heating networks causes a significant economic effect $[12,22]$.

It is important to note that there are several classifications of ways to improve the designs of plate heat exchangers. Among the known directions of modernization of the design of plate heat exchangers, the major ones can be pinpointed:

- changing the geometry of the heat exchange surface;

- the use of mechanical turbulators;

- the use of external physical fields;

- the use of solid particles in the coolant.

Let us look at these areas in more detail.

Changing the geometry of the heat transfer surface for lamellar devices consists in that of the shape of the plate surface. Therefore A. Yu. Maskinskaya at the Moscow Power Engineering Institute developed a plate with spherical dimples [7]. The result of the study was the identification of dependencies suitable for calculating characteristics in heat power facilities given the influence of the depth of the dimples, the height of the channel and the degree of turbulence characteristic of the developed currents. 
The work by the Italian specialists R. Morreti and M. Ereira [23] on the use of plates with different corrugation heights is of interest. This made it possible to increase the heat transfer by $10 \%$, however, with such a modification, an increase in pressure losses is observed at high speeds.

The impact on the flow of mechanical turbulators is created, as noted by A. P. Zegzhda, by adding deflectors of various geometric shapes [2], which contribute to the rational separation of coolant flows to reduce the hydraulic resistance $\mathrm{H}, \mathrm{m}$, and increase the heat transfer coefficient $\mathrm{K}, \mathrm{W} /\left(\mathrm{m}^{2} \mathrm{~K}\right)$.

The use of external physical fields, particularly acoustic vibrations, made it possible to increase the values of the average heat transfer coefficients only at an intensity of vibrations above $140 \mathrm{~dB}$, which is dangerous for human hearing [8]. The use of ultrasonic vibrations increased the efficiency of the heat transfer process by 5 times, however, according to studies in degassed water, a slight intensification was noted [25].

In order to intensify heat transfer, solid particles are used in the coolant, e.g., ferrimagnetic particles are introduced moving under the action of a rotating magnetic field [1, 20, 24]. According to the official representatives of Alfa Laval in Russia, the heat transfer coefficient increases by $40 \%$, but filters must be set up at the inlet and outlet of the apparatus. Investigations were conducted related to the use of a heating circuit coolant, which included a nanofluid, which is a suspension of copper and zinc nanoparticles [6]. At the same time, the maximum - 1.5 times the heat transfer went up with the use of copper. This method of intensification is only possible in the chemical, petrochemical and food industries, and for them to be employed in in heat supply, specialized boiler and pumping equipment will have to be used [16, 19, 26].

Note that active methods of intensifying the heat exchange process require the use of thirdparty devices causing an increase in the energy consumption and thereby an increase in the maintenance and repair costs.

An alternative option is the use of passive methods acting on the boundary layer due to the application of ribbing, the use of rough surfaces, swirlers and other developed heat exchange surfaces $[17,21]$. Complex methods of intensification of the heat exchange process are also utilized combining several methods in one technological process, e.g., a combination of rough surfaces and swirlers [18, 20].

A feature of the device of plate heat exchangers is the design and shape of the heat exchange surface and channels for the operating environment. The heat exchange surface is formed from separate plates, and the channels for the operating environment have a slot-like shape. The ope- 
rating environments move at the heat exchange surface in a thin layer, which contributes to the intensification of the heat transfer process. The shapes of the plates and their surface profiles are shown in Fig. 2.

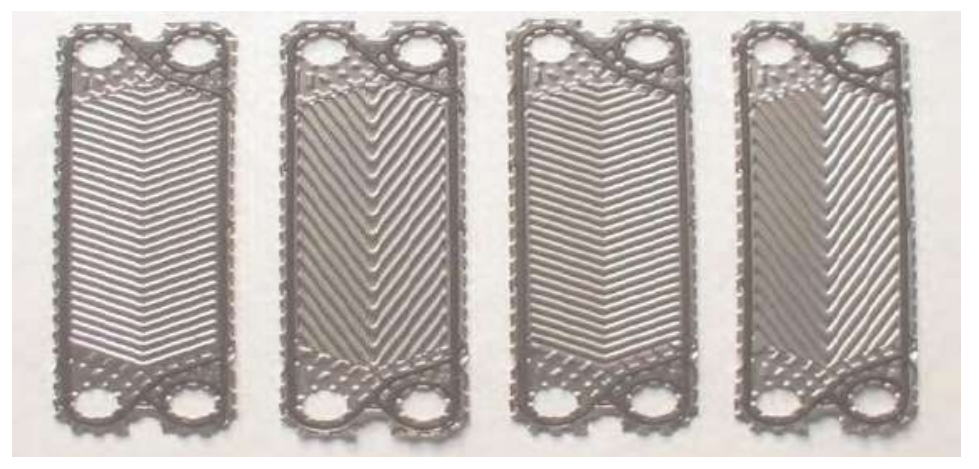

Fig. 2. Shapes of the plates and profiles of the surfaces

a)

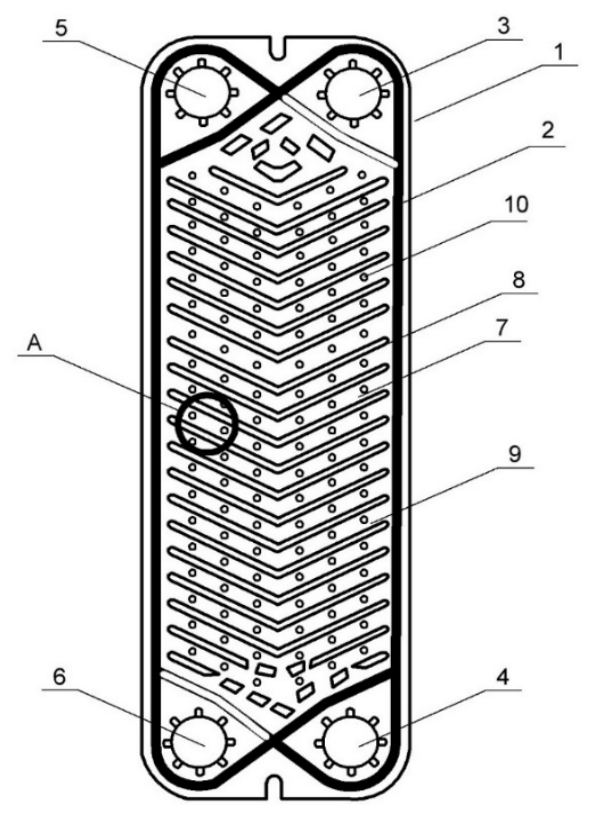

b)

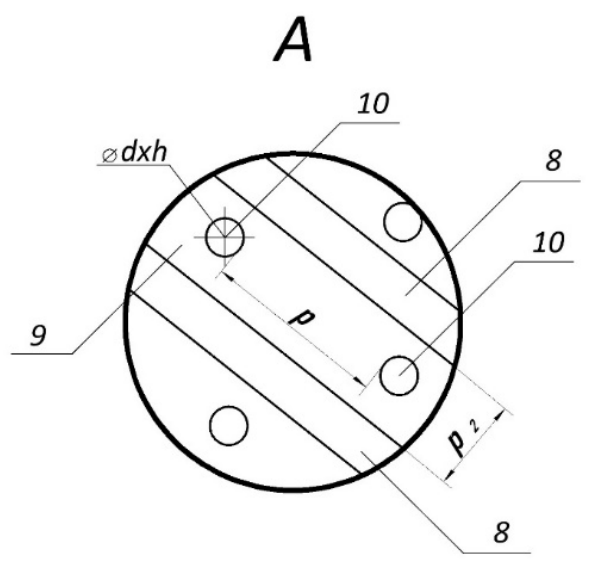

Fig. 3. Heat exchanger plate:

a) general view of the plate; b) view A; 1 - metal plate serving as the basis of the product; 2 - a sealing gasket; 3 - outlet of the heated circuit; 4 - inlet of the heated circuit; 5- heating circuit inlet; 6 - outlet of the heating circuit; 7 - the main heat exchange part; 8 - corrugation (corrugation); 9 - area between adjacent corrugations; 10 - technological recess of a spherical shape; $d$ is the diameter of the recess, $\mathrm{m} ; h$ is the height of the recess, $\mathrm{m} ; p$ is the step of the indentations, $\mathrm{m} ; p_{2}$ - distance between adjacent corrugations, $\mathrm{m}$

In order to intensify the heat transfer, an original design of an intensified plate heat exchanger with modified corrugated plates [9] is set forth whose design feature is the corrugated heat 
exchange plates shown in Fig. 3. The developed plates have spherical grooves located according to a linear law, i.e., between adjacent corrugations of the main heat exchange part.

\section{Experimental heat engineering studies of an intensified plate heat exchanger in a}

laboratory setup. Conducting field experimental studies is necessary to establish the effect on the efficiency of the intensified plate heat exchanger with the increased turbulization of the coolant of the following factors:

1) the flow rate of the heating agent in the heating and heating circuits, $G_{g r} ; G_{n g}, \mathrm{~m}^{3} / \mathrm{h}$;

2) the values of the liquid temperature at the inlet to the heating and heated circuits of the intensified plate heat exchanger, $\mathrm{t}_{1 g r}, \mathrm{t}_{1 n g},{ }^{0} \mathrm{C}$.

Experimental studies were performed in a specialized laboratory of BSTU named after V. G. Shukhov at the laboratory setup "Independent Heating System of a Residential Building". At the same time, the safety requirements were observed. The aim of the experiment is to compare the heat and power and hydrodynamic characteristics of two devices:

- serial plate heat exchanger designed in compliance with GOST (ГОСТ) 15518-87;

- original intensified plate heat exchanger with corrugated plates containing spherical technological recesses.

Table

Physical and chemical characteristics of coolants

\begin{tabular}{|c|c|c|}
\hline № & Parameter & Value \\
\hline \multicolumn{3}{|c|}{ Heating contour } \\
\hline 1 & Density, $\mathrm{kg} / \mathrm{m}^{3}$ & 998 \\
\hline 2 & Rigidity, mmole/l & 8 \\
\hline 3 & Turbidity, cm & $27-29$ \\
\hline 4 & Specific heat capacity, kJ/(kg K) & 4.2 \\
\hline 5 & Maximum temperature, ${ }^{\circ} \mathrm{C}$ & 85 \\
\hline \multicolumn{3}{|c|}{ Heated contour } \\
\hline 6 & Density, $\mathrm{kg} / \mathrm{m}^{3}$ & 998 \\
\hline 7 & Rigidity, mmole/l & 8 \\
\hline 8 & Turbidity, cm & $27-29$ \\
\hline 9 & Specific heat capacity, kJ/(kg K) & 4.2 \\
\hline 10 & Minimum temperature, ${ }^{0} \mathrm{C}$ & 20 \\
\hline
\end{tabular}

General view of the laboratory installation "Independent heating system of a residential building" is shown in Fig. four. 
An intensified plate heat exchanger, the main element of which is a modified corrugated plate with spherical depressions located according to a linear law [9], between adjacent corrugations, is the central element of the laboratory setup.

The table shows the physical and chemical characteristics of the coolants used in the experiments.

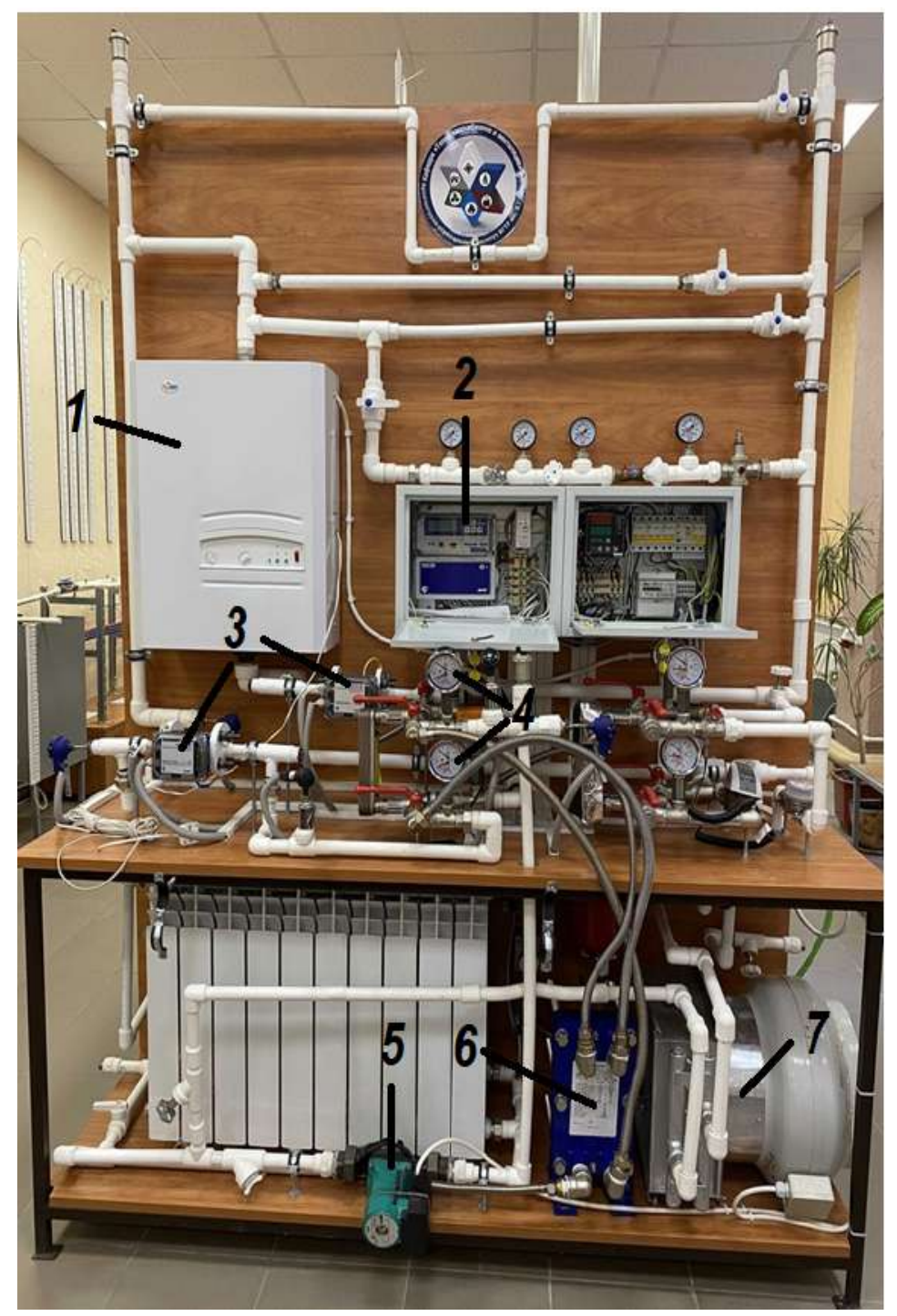

Fig. 4. Laboratory setup "Independent Heating System of a Residential Building":

1 - hot water electric boiler "Rusnit"; 2 - heat calculator "Vzlet TSRV-042"; 3 - Vzlet flow meters;

4 - manometers; 5 - circulation pump Grundfoss UPS 32-40;

6 - intensified plate heat exchanger; 7 - heater

The piping of the experimental setup is made with polymer pipelines with a diameter of $D y=15$; twenty; 25; $32 \mathrm{~mm}$. Shut-off valves (ball valves) and control valves (valves) of corresponding diameters were set up. 
According to SP (CП) 41-01-95 "Designing Heat Points", the heat transfer coefficient K, $\mathrm{W} /\left(\mathrm{m}^{2} \mathrm{~K}\right)$, for plate heat exchangers is calculated:

$$
K=\frac{\beta}{\frac{1}{\alpha_{1}}+\frac{1}{\alpha_{2}}+\frac{\delta_{C T}}{\lambda_{C T}}},
$$

where $\beta$ is the coefficient taking into consideration the decrease in the heat transfer coefficient due to the thermal resistance of scale and impurities on the plate depending on the quality of the water, is taken equal to $0.7-0.85 ; \alpha_{1}$ is the coefficient of heat transfer from heating water to the plate wall, Watt $/\left(\mathrm{m}^{2} \mathrm{~K}\right) ; \alpha_{2}$ is the coefficient of heat absorption from the wall of the plate to the heated water, Watt $/\left(\mathrm{m}^{2} \mathrm{~K}\right) ; \delta_{C T}$ is the thickness of the heat exchange plate, $\mathrm{m}$; $\lambda_{C T}$ is the coefficient of the heat conductivity of the plate material, Watt $/\left(\mathrm{m}^{2} \mathrm{~K}\right)$.

As a result of the research, the optimal operating modes of the investigated plate heat exchanger with increased turbulization have been identified.

It has been shown experimentally that the use of corrugated plates with spherical depressions arranged according to a linear law causes an increase in the heat transfer coefficient $\mathrm{K}$, $\mathrm{W} /\left(\mathrm{m}^{2} \mathrm{~K}\right)$, and an intensification of heat transfer, which is confirmed in Fig. 5.

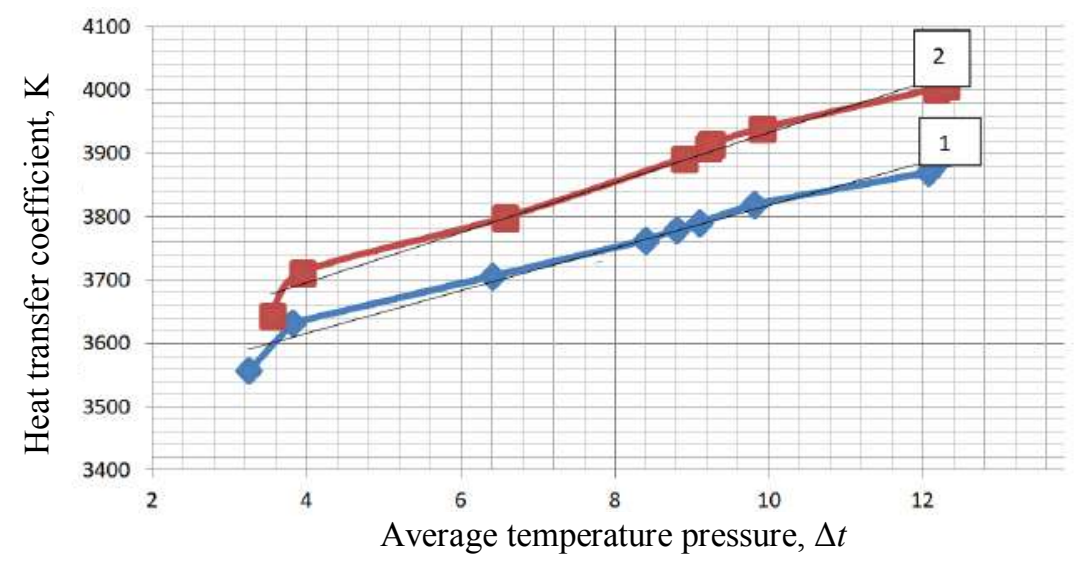

Fig. 5. Graph of the dependence of the heat transfer coefficient on the average temperature pressure: 1 - serial heat exchanger; 2 - plate heat exchanger with corrugated plates with spherical grooves

It can be concluded that the use of corrugated plates with spherical grooves arranged according to a linear law causes an increase in the efficiency of the plate heat exchange equipment and the overall reduction in the cost of heating (cooling) of the coolant.

\section{Conclusions}

1. The use of plates with technological depressions of a spherical shape, arranged according to a linear law, makes it possible to increase the efficiency of heat transfer between two heat car- 
riers, e.g., liquids, by increasing the heat transfer coefficient by intensifying the turbulence of the heat carrier flow in the heat exchanger. In this case, additional vortex formation occurs at the "heat carrier - plate" interface.

2. Intensification of heat exchange processes is achieved by using spherical grooves located according to a linear law.

3. The results of the experimental studies of two plate heat exchangers confirm the advantage of using modified corrugated plates.

4. It is our belief that further research in the field of intensification of heat exchange processes would increase the reliability of heat supply systems and reduce the maintenance costs.

\section{References}

1. Grabezhnaya V. A., Kirillov P. L. Teploobmen pri sverkhkriticheskikh davleniyakh granitsy ukhudsheniya teploobmena [Heat transfer at supercritical pressures limits of heat transfer degradation]. Teploenergetika, 2006, no. 4, pp. 46-51.

2. Zegzhda A. P. Gidravlicheskie poteri v kanalakh i truboprovodakh [Hydraulic losses in channels and pipelines]. Moscow, Gosstroiizdat Publ., 1957. 503 p.

3. Kushchev L. A., Nikulin N. Yu., Feoktistov A. Yu., Yakovlev E. A. Intensifikatsiya teplovykh protsessov v kozhukhotrubnom teploobmennom apparate [Intensification of thermal processes in a shell-and-tube heat exchanger]. Nauchnyi vestnik Voronezhskogo GASU. Stroitel'stvo i arkhitektura, 2016, no. 3, pp. 9-17.

4. Kushchev L. A., Nikulin N. Yu. [Application of heat exchangers in industry]. Materialy mezhdunar. nauch.-prakt. konf "Tekhnosfernaya bezopasnost', nadezhnost', kachestvo, energo- i resursosberezhenie" [Proc. "Technosphere safety, reliability, quality, energy and resource conservation"]. Rostov-on-Don, Izd-vo RGSU, 2015, vol. XVII, iss. 1, pp. 204-210.

5. Lobanov I. E. Modelirovanie teploobmena pri turbulentnom techenii v ploskikh kanalakh s simmetrichnymi turbulizatorami na obeikh storonakh [Modeling of heat exchange during turbulent flow in flat channels with symmetrical turbulators on both sides]. Vestnik Dagestanskogo gosudarstvennogo tekhnicheskogo universiteta. Tekhnicheskie nauki, 2019, no. 1, pp. 53-65.

6. Marksis'ko O. R. Ekonomicheskaya effektivnost' intensifikatsii teploobmena pri ispol'zovanii poverkhnostno-aktivnykh veshchestv [Economic efficiency of heat exchange intensification when using surfactants]. Nauchnyi vestnik LNUVMBT im. S. Z. Izhits'kogo, 2015, no. 1, pp. 60-65.

7. Maskinskaya A. Yu. [Experimental and computational studies in a channel with holes on the lower wall]. Tez. dokladov 10-i mezhdunar. nauch.-tekhn. konf. studentov i aspirantov "Radioelektronika, elektrotekhnika i energetika" [Proc. "Radio electronics, electrical engineering and power engineering"]. Moscow, 2004, pp. 348 -349.

8. Noto K., Matsumoto R. Turbulentnyi perenos tepla pri svobodnoi konvektsii vdol' izotermicheskoi vertikal'noi ploskoi poverkhnosti [Turbulent heat transfer under free convection along an isothermal vertical flat surface]. Teploperedacha, 1975, no. 4, 139 p.

9. Kushchev L. A., Savvin N. Yu., Feoktistov A. Yu. Plastina teploobmennika [Heat exchanger plate]. Patent RF, 2020, no. 199344. 
10. Romanenko V. A. Izmeneniya klimata v Rossii. Prichiny i posledstviya [Climate change in Russia. Causes and consequences]. Molodoi uchenyi, 2019, no. 7, pp. 1-5.

11. Rudskoi A. I., Lunev V. A. Matematicheskoe modelirovanie gidrodinamiki i teploobmena $v$ dvizhushchikhsya zhidkostyakh [Mathematical modeling of hydrodynamics and heat transfer in moving fluids]. SaintPetersburg, Lan' Publ., 2015. 208 p.

12. Savvin N. Yu., Nikulin N. Yu. [Highly efficient heat exchanger for the housing and communal services system]. Sb. nauch. tr. "Nauka. Tekhnologii. Innovatsii” [The science. Technologies. Innovations]. Novosibirsk, NGTU Publ., 2019, pp. 256-262.

13. Savvin, N. Yu. [Improvement of the design of the plate heat exchanger]. Mezhdunar. nauch.-tekhn. konf. molodykh uchenykh [International Scientific and Technical University conf. of young scientists]. Belgorod, BGTU im. V. G. Shukhova, 2020, pp. 2240-2244.

14. Tsygankov A. S. Raschety teploobmennykh apparatov [Calculations of heat exchangers]. Saint-Petersburg, SUDPROMGIZ Publ., 1956. 135 p.

15. Yakovlev B. V. Povyshenie effektivnosti sistem teplofikatsii i teplosnabzheniya [Improving the efficiency of heating and heat supply systems]. M., Novosti teplosnabzheniya Publ., 2013. 448 p.

16. Gulenoglu. C., Akturk F., Aradag S., Sezer N., Uzol S. Kakac Experimental comparison of performances of three different plates for gasketed plate heat exchangers. International Journal of Thermal Sciences, 2014 , no. 75 , pp. $249-256$.

17. Gupta A. K., Kumar P., Sahoo R. K., Sahu A. K., Sarangi S. K. Performance measurement of plate fin heat exchanger by exploration: ANN, ANFIS, GA, and SA. Journal of Computational Design and Engineering, 2016, no. 4 , pp. $60-68$.

18. Huikun C., Lijun S., Yidai L., Zeju W. Numerical and experimental study on the influence of top bypass flow on the performance of plate fin heat exchanger. Applied Thermal Engineering, 2018, no. 146, pp. 356-363.

19. Kexin X., Robin S., Nan Z. Design and optimization of plate heat exchanger networks. Computer Aided Chemical Engineering, 2017, no. 40, pp. 1819-1824.

20. Khujaev P. S., R. G. Abdullaev, A. J. Rahmonzoda Radiative heat transfer in the furnace space with variable volume. Polytechnic bulletin. Series: Engineering research, 2019, no. 1 (45). pp. 223-227.

21. Kolesnikov I. P., Danilchenko S. E. Modelling of thermoelastic transient contact interaction for binary bearing taking into account convection. Transport Problems, 2016, no. 4, pp. $73-81$.

22. Kushchev, L. A., Nikulin N. Yu., Alifanova A. I., Feoktistov A. Yu. Intensity enhancement of heat exchange in shell-tube heat exchangers with smooth pipes. Advances in Engineering Research, 2017, no. 133, pp. 390-395.

23. Moretti R., Errera M., Couaillier V., Feyel F. Effect of the perforation design on the fluid flow and heat transfer characteristics of a plate fin heat exchanger. International Journal of Thermal Sciences, 2018, no. 126, pp. $172-180$.

24. Vasil'ev E. N. Calculation of heat transfer characteristics of a finned wall. Siberian Journal of Science and Technology, 2020, no. 2, pp. 226-232.

25. Wang J., Lan S., Chen G. Experimental study on the turbulent boundary layer flow over riblets surface. Fluid Dyn. Res, 2000, no. 4, p. 27.

26. Wagh P., Pople M. U. Optimization of a Shell and Tube Condenser using Numerical Method. Int. Journal of Engineering Research and Applications, 2015, vol. 7, pp. 9-15. 